\title{
Variability study of entomopathogenic nematode populations (Heterorhabditidae) from Argentina
}

\author{
M. F. Achinelly ${ }^{a}$, D. P. Eliceche ${ }^{a}$, M. N. Belaich ${ }^{b}$ and P. D. Ghiringhelli ${ }^{b}$ \\ ${ }^{a}$ Consejo Nacional de Investigaciones Científicas y Técnicas - CONICET, Centro de Estudios Parasitológicos y de \\ Vectores - CEPAVE, Facultad de Ciencias Naturales y Museo, Universidade Nacional de La Plata - UNLP, \\ Calle 60 y 121, s/n, La Plata, Buenos Aires, Argentina \\ ${ }^{b}$ Laboratorio de Ingeniería Genética y Biología Celular y Molecular, Consejo Nacional de Investigaciones Científicas \\ y Técnicas - CONICET, Universidad Nacional de Quilmes - UNQ, Roque Sáenz Peña, 352, Bernal, Buenos Aires, \\ Argentina \\ *e-mail: fachinelly@cepave.edu.ar
}

Received: November 24, 2015 - Accepted: April 14, 2016 - Distributed: August 31, 2017

(With 2 figures)

\begin{abstract}
Entomopathogenic nematodes (EPN) belonging to the Heterorhabditidae family are lethal parasites of soil-dwelling insects. Two species were reported in Argentina: Heterorhabditis argentinensis and Heterorhabditis bacteriophora characterized mainly by morphometric features. In this work a comparative and phylogenetic study between five Heterorhabditis populations from Argentina was conducted to analyze the variability between strains and to evaluate the taxonomic position of Heterorhabditis argentinensis. The PCA analyses of morphometric characters separated the larger juvenile, female and male H. argentinensis from H. bacteriophora populations. The juvenile (IJs) stage provided the clearest separation of Heterorhabditis populations presenting the least variability between strains. The variable $\mathrm{L}$ and MBW were highly related to $H$. argentinensis IJs. Three groups were separated by this stage considering PC1 and PC2: one formed by H. bacteriophora OLI, RIV and RN strains, (isolates from Córdoba and Río Negro province), one for H. bacteriophora VELI strain (Buenos Aires province) and one for H. argentinensis (Santa Fe province). Heterorhabditis bacteriophora VELI and $H$. argentinensis isolated from regions with more rainfalls and humidity presented larger values for morphometric features. Molecular analyses showed the Argentinian populations (H. bacteriophora VELI strain and $H$. argentinensis), forming a same clade, with six other H. bacteriophora populations (not from Argentina) with a genetic similarity between them of $99 \%$. Heterorhabditis argentinensis presented one unique nucleotide that was not present in any of the other species of the clade. Considering the results of this study H. argentinensis would be conspecific to $H$. bacteriophora, constituting a strain with a great morphometric variation where the host and climatic conditions could have influenced on the measurements.
\end{abstract}

Keywords: entomonematodes, Heterorhabditidae, variability, strains, Argentina.

\section{Estudo da variabilidade entomopatogênicos nematóides populações (Heterorhabditidae) da Argentina}

\section{Resumo}

Nematóides entomopatogênicos (EPN) pertencentes à família Heterorhabditidae são parasitas letais de insetos que vivem no solo. Duas espécies foram relatados na Argentina: Heterorhabditis argentinensis e Heterorhabditis bacteriophora, caracterizada principalmente por características morfométricas. Neste trabalho um estudo comparativo e filogenética entre cinco populações do Heterorhabditis da Argentina foi conduzido para analisar a variabilidade entre as linhagens e avaliar a posição taxonômica das Heterorhabditis argentinensis. Características morfométricas de Heterorhabditis bacteriophora VELI e H. argentinensis isoladas de regiões com mais chuvas e umidade apresentaram dimensões maiores. Analisa o PCA de personagens morfométricas separou a maior juvenil, feminino e masculino H. argentinensis de H. bacteriophora populações. A fase juvenil (JIs) fornece a mais clara separação de populações Heterorhabditis apresentando a menor variação entre as cepas. A L variável e MBW foram altamente relacionada com $H$. argentinensis JIs. Três grupos foram separados por esta fase considerando PC1 e PC2: um formado por H. bacteriophora OLI, RIV e estirpes RN, (isolados de Córdoba e província de Rio Negro), um para a estirpe H. bacteriophora VELI (província de Buenos Aires) e um para H. argentinensis (província de Santa Fe). Heterorhabditis bacteriophora VELI e H. argentinensis isolado a partir de regiões com mais chuvas e umidade apresentaram maiores valores para as características morfométricas. A análise molecular mostrou as populações da Argentina (estirpe H. bacteriophora VELI e H. argentinensis), formando um mesmo subtipo, com seis outras populações H. bacteriophora (não da Argentina), 
com uma similaridade genética entre eles de 99\%. Heterorhabditis argentinensis apresentado um único nucleótido que não estava presente em nenhum dos outros espécies do clado. Considerando os resultados deste estudo H. argentinensis seria conspecific a H. bacteriophora, constituindo uma estirpe com uma grande variação morfométrica onde o anfitrião e as condições climáticas podem ter influenciado nas medições.

Palavras-chave: entomonematodes, Heterorhabditidae, variabilidade, cepas, Argentina.

\section{Introduction}

Entomopathogenic nematodes (Heterorhabditidae), are generalized consumers of insects in soil food webs that occur widely in natural and agricultural ecosystems. Their associations with symbiotic pathogenic bacteria make them highly virulent, constituting an alternative for the control of insect pests. The third juvenile stage of entomopathogenic nematodes is referred to as the "infective juvenile" or "dauer" stage and is the only free-living stage. They are capable of surviving in the soil without nourishment for prolonged periods up it locates, attacks, and infects an insect host. Once inside the host hemocoel, the IJ releases symbiotic bacteria and kills the host by a combination of toxins and septicemia. Soon after, the IJs begin to feed on the bacteria and develop to reproductive stages. Infective juveniles of the genus Heterorhabditis present a first generation of adult hermaphrodites and generally, a second generation with males and true females. Finally, IJs leave the cadavers in response to declining nutrients. Thus, a single IJ has the potential to colonise a new habitat (Boff et al., 2000).

Two species of heterorhabditid nematodes were cited for Argentina: Heterorhabditis argentinensis Stock, 1993 in Santa Fe and La Pampa provinces, and Heterorhabditis bacteriophora Poinar, 1976, reported in Buenos Aires, Cordoba, La Pampa, Neuquén, Río Negro, Mendoza and Santa Fe provinces (Stock, 1993, 1995; Doucet and Bertolotti, 1996; Giayetto and Cichón, 2006; Del Valle et al., 2013). These strains were characterized mainly by morphological and morphometric features. In this way, Heterorhabditis argentinensis was reported and characterized at first, by the large size of the adult males and first-generation females, the longer tail, and the peloderan bursa with 9 pairs of genital papillae in the arrangement 1, 2, 1, 2, 3 (Stock, 1993). However, Adams et al. (1998) considered H. argentinensis and $H$. bacteriophora species as sister taxa and possibly even conspecific by PCR amplification of the ITS-1 region. Even, Nguyen (2016) mentioned the arrangement of the last three genital papillae of the bursa, as highly variable in strains of Argentina.

The nematode stage and main traits that should be used for Heterorhabditis species distinctions is a matter of discussion. Several authors considered morphological and morphometric features of males and IJs as the most suitable for the distinction among heterorhabditid populations (Adams et al., 1998; Dolinski et al., 2008). Body (L) and tail (T) length in IJs, plus body (L) and reflection of testis in males were used to identify Heterorhabditis species (Hominick et al., 1997). However, Phan et al. (2003) suggest length in IJs, and spicule and gubernaculum length and shape in males as ones that should be considered.
Stock and Mrácek (2000), suggested that geographical origin and habitat can influence morphometric data. Intraspecific morphometric variations were observed among strains of the entomopathogenic nematode Steinernema feltiae from UK, Pakistan, Rioja and Catalonia (Spain). Also, differences were observed for IJs and males from different infected hosts (Campos Herrera et al., 2006).

Considering the number of Heterorhabditis populations isolated from different regions from Argentina, the lack of variability studies for this region and the discussion about the position of $H$. argentinensis, the aims of this work was to analyze morphometric variability between Argentinian strains of Heterorhabditis spp. and to evaluate the taxonomic position of $H$. argentinensis.

\section{Material and Methods}

\subsection{Morphometric study of Heterorhabditis spp. populations}

Five populations of Heterorhabditis spp. isolated from Argentina were considered. Measurements of morphometric features were taken from the literature: Heterorhabditis bacteriophora RIV from Río Cuarto city, Córdoba province $\left(33^{\circ} 08^{\prime} 00^{\prime \prime} \mathrm{S} ; 64^{\circ} 21^{\prime} 00^{\prime \prime} \mathrm{W}\right)$ OLI strain, from Oliva,

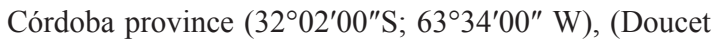
and Bertolotti, 1996; Doucet et al., 1996), RN strain from Río Negro province $\left(38^{\circ} 56^{\prime} 00^{\prime \prime} \mathrm{S} 68^{\circ} 01^{\prime} 00^{\prime \prime} \mathrm{W}\right.$ ) (Doucet and Bertolotti, 1996), VELI strain from Villa Elisa, Buenos Aires province (3451'12" S, 58 $04^{\circ} 45^{\prime}$ 'W) (Salas et al., 2013), and H. argentinensis isolated from Rafaela, Santa Fe province ( $\left.31^{\circ} 16^{\prime} 00^{\prime \prime} \mathrm{S} 61^{\circ} 29^{\prime} 00^{\prime \prime} \mathrm{W}\right)$ (Stock, 1993). Data of the climatic conditions for regions where nematodes were isolated, are shown in Table 1.

Principal component analyses (PCA) were performed on the morphometric variables representing data of hermaphroditic females, amphimictic females, males and infective juveniles of the Heterorhabditis species, to examine the general grouping of all individuals with Infostat statistical program (version 2014). Six variables were considered for hermaphroditic females: L, MBW, NR, EP, ES, TL, and V; eight for amphimictic females: L, MBW, NR, EP, ES, TL, ABW and V; nine for males: L, MBW, NR, EP, ES, TRL, TL, SpL and GuL; and five for infective juveniles: L, MBW, EP, ES and TL (as shown in Tables 2-5).

\subsection{Molecular-genetic analyses}

The genetic variability among Argentinian populations was analyzed. Heterorhabditis argentinensis was molecularly characterized by DNA sequences of the ITS1 region (Adams et al., 1998), so this nucleotide sequence was 
Table 1. Climatic conditions of origin regions of entomopathogenic nematodes strains considered in this study (H. b: H. bacteriophora).

\begin{tabular}{lccccc}
\hline \multicolumn{1}{c}{ Origin } & H.b. VELI & H.b. OLI & H.b. RIV & H.b. RN & H. argentinensis \\
\hline Coordinates & $\begin{array}{c}34^{\circ} 51^{\prime} 12^{\prime \prime} \mathrm{S}, \\
58^{\circ} 04^{\prime} 45^{\prime \prime} \mathrm{W}\end{array}$ & $\begin{array}{c}32^{\circ} 02^{\prime} 00^{\prime \prime} \mathrm{S} ; \\
63^{\circ} 34^{\prime} 00^{\prime \prime} \mathrm{W}\end{array}$ & $\begin{array}{c}33^{\circ} 08^{\prime} 00^{\prime \prime} \mathrm{S} ; \\
64^{\circ} 21^{\prime} 00^{\prime \prime} \mathrm{W}\end{array}$ & $\begin{array}{c}38^{\circ} 56^{\prime} 00^{\prime \prime} \mathrm{S} ; \\
68^{\circ} 01^{\prime} 00^{\prime \prime} \mathrm{W}\end{array}$ & $\begin{array}{c}31^{\circ} 16^{\prime} 00^{\prime \prime} \mathrm{S} \\
61^{\circ} 29^{\prime} 00^{\prime \prime} \mathrm{W}\end{array}$ \\
\hline Geography & Plain & Plain & Plain & Plain & Plain \\
\hline $\begin{array}{l}\text { temperate and } \\
\text { humid }\end{array}$ & $\begin{array}{c}\text { temperate and } \\
\text { semi arid }\end{array}$ & $\begin{array}{c}\text { temperate and } \\
\text { semi arid }\end{array}$ & $\begin{array}{c}\text { temperate and } \\
\text { dry }\end{array}$ & $\begin{array}{c}\text { temperate and } \\
\text { humid }\end{array}$ \\
\hline $\begin{array}{l}\text { Mean annual } \\
\text { max. temp. }\left({ }^{\circ} \mathrm{C}\right)\end{array}$ & 11 & 10 & 10 & 8 & 12 \\
\hline $\begin{array}{l}\text { Mean annual } \\
\text { min. temp. }\left({ }^{\circ} \mathrm{C}\right)\end{array}$ & 21 & 24 & 22 & 21 & 25 \\
\hline $\begin{array}{l}\text { Mean annual } \\
\text { temp. }\left({ }^{\circ} \mathrm{C}\right)\end{array}$ & 15.8 & 16.9 & 16.8 & 14.1 & 18 \\
\hline $\begin{array}{l}\text { Total annual } \\
\text { rainfall }(\mathrm{mm})\end{array}$ & 1007 & 711 & 846 & 213 & 959 \\
\hline \begin{tabular}{l} 
Humidity $(\%)$ \\
\hline
\end{tabular} & 77 & 67 & 68 & 56 & 76 \\
\hline
\end{tabular}

Table 2. Morphometrics (mean and range) of hermaproditic females of Heterorhabditis isolates provided by the bibliography. All measurements are in $\mu \mathrm{m}$ (H. b: H. bacteriophora; NA: not available).

\begin{tabular}{|c|c|c|c|c|c|}
\hline \multirow{2}{*}{ Characters } & \multicolumn{5}{|c|}{ Hermaprhroditic females } \\
\hline & H.b. VELI & H.b. OLI & H.b. RIV & H.b. RN & H. argentinensis \\
\hline \multirow[t]{2}{*}{$\mathrm{L}$} & $2,835.46 \pm 482.72$ & $4,800 \pm 550$ & $5,010 \pm 410$ & $3,460 \pm 780$ & 6,500 \\
\hline & $(2,160-3,840)$ & $(3,900-5,800)$ & $(4,200-5,600)$ & $(2,400-4,800)$ & $(5,000-7,500)$ \\
\hline \multirow[t]{2}{*}{ MBW } & $117.64 \pm 14.32$ & $215.7 \pm 27.64$ & $202.6 \pm 16.99$ & $185.75 \pm 24.03$ & 360 \\
\hline & (97.4-138.65) & $(177.5-255)$ & $(175-242)$ & $(145-222.5)$ & $(250-275)$ \\
\hline \multirow[t]{2}{*}{ VBW } & $123.60 \pm 17.54$ & NA & NA & NA & NA \\
\hline & $(109.04-153.12)$ & & & & \\
\hline \multirow[t]{2}{*}{ STL } & $8.91 \pm 2.10$ & $11.13 \pm 1.9$ & NA & NA & 13 \\
\hline & $(6.25-11.6)$ & $(7.5-15)$ & & & $(10.0-16.0)$ \\
\hline \multirow[t]{2}{*}{ STW } & $8.16 \pm 1.34$ & $11.13 \pm 1.89$ & NA & NA & 10 \\
\hline & $(5.87-9.28)$ & $(7.5-12.5)$ & & & $(6.0-12)$ \\
\hline \multirow[t]{2}{*}{ NR } & $88.95 \pm 1.34$ & $77.88 \pm 7.71$ & $138.86 \pm 8.37$ & $136.41 \pm 17.26$ & 160 \\
\hline & $(69.6-118.7)$ & $(67.5-92.5)$ & $(125-152)$ & $(107.5-167.5)$ & $(132-196)$ \\
\hline \multirow[t]{2}{*}{ EP } & $157.65 \pm 19.89$ & $194.38 \pm 15.53$ & $189.93 \pm 13.65$ & $175.58 \pm 23.27$ & 294 \\
\hline & $(132.24-200)$ & $(175-225)$ & $(163-225)$ & $(142.5-212.5)$ & $(250-340)$ \\
\hline \multirow[t]{2}{*}{ ES } & $152.58 \pm 16.41$ & $183.7 \pm 14.06$ & $199.03 \pm 8.25$ & $189.41 \pm 23.83$ & 274 \\
\hline & (132.22-181.25) & $(162.5-207)$ & $(180-220)$ & $(155-225)$ & $(235-300)$ \\
\hline \multirow[t]{2}{*}{$\mathrm{TL}$} & $47.87 \pm 9.46$ & $81 \pm 7.09$ & $72.8 \pm 7.09$ & $61.16 \pm 8.97$ & 118 \\
\hline & $(37.5-51.04)$ & $(70-95)$ & $(50-87)$ & $(47.5-87.5)$ & $(100-140)$ \\
\hline \multirow[t]{2}{*}{$\mathrm{ABW}$} & $52.41 \pm 17.80$ & $48.5 \pm 6.24$ & $53.3 \pm 3.66$ & $35.16 \pm 9.3$ & 86 \\
\hline & $(37.12-63.45)$ & $(35.5-59)$ & $(45-62)$ & $(22.5-55)$ & $(70-120)$ \\
\hline \multirow[t]{2}{*}{$\mathrm{V}$} & $42.15 \pm 12.79$ & $41.83 \pm 2.1$ & $40.53 \pm 1.54$ & $45.8 \pm 2.96$ & 44.5 \\
\hline & $(39.86-47)$ & $(36.1-45.1)$ & $(35-45)$ & $(39.53-50.9)$ & $(40-50)$ \\
\hline
\end{tabular}

considered as limit length, of the segments of analyzed species. A set of 37 homologous sequences recovered from GenBank were aligned with other ITS1 rDNA for bioinformatic analyses. Longer sequences were shortened in order to have a common informative genome segment.

Among five isolates compared in the morphometric study, only H. bacteriophora (VELI strain) and H. argentinensis were included in the phylogenetic analysis because there are no records of sequences for ITS-1 region in the Genbank for the rest. The evolutionary history was inferred by means of the neighbor-joining method (Saitou and Nei, 1987). The evolutionary distances were computed by means of the maximum-composite-likelihood method (Tamura et al., 2004 ) and the rate of variation among loci modeled with 
Table 3. Morphometrics (mean and range) of amphimictic females of Heterorhabditis isolates provided by the bibliography. All measurements are in $\mu \mathrm{m}$ (H. b: H. bacteriophora; NA: not available).

\begin{tabular}{|c|c|c|c|c|c|}
\hline \multirow{2}{*}{ Characters } & \multicolumn{5}{|c|}{ Amphimictic females } \\
\hline & H.b. VELI & H.b. OLI & H.b. RIV & H.b. RN & H. argentinensis \\
\hline \multirow[t]{2}{*}{$\mathrm{L}$} & $1,646.34 \pm 282.42$ & $2,220 \pm 210$ & $2,140 \pm 170$ & $1,830 \pm 120$ & 3,000 \\
\hline & $(1,251-2,286)$ & $(1,800-2,600)$ & $(1,800-2,400)$ & $(1,650-2,150)$ & $(2,000-3,500)$ \\
\hline \multirow[t]{2}{*}{ MBW } & $97.08 \pm 11.89$ & $114.13 \pm 9.81$ & $123.46 \pm 13.39$ & $112.9 \pm 8.2$ & 130 \\
\hline & $(78.8-113.68)$ & $(97.5-133)$ & (100-162) & $(95-127.5)$ & $(90-180)$ \\
\hline \multirow[t]{2}{*}{ STL } & $7.76 \pm 1.36$ & $7.88 \pm 1.47$ & NA & NA & 9.5 \\
\hline & $(6.96-11.6)$ & $(5.0-10.0)$ & & & $(7-12)$ \\
\hline \multirow[t]{2}{*}{ STW } & $7.22 \pm 0.69$ & $8.25 \pm 1.43$ & NA & NA & 8 \\
\hline & $(6.96-9.28)$ & $(5.0-10.0)$ & & & $(5-10)$ \\
\hline \multirow[t]{2}{*}{ NR } & $73.69 \pm 13.56$ & $65 \pm 7.43$ & $93.23 \pm 5.2$ & $95.75 \pm 6.47$ & 114 \\
\hline & $(58-104.4)$ & $(55-87.5)$ & $(83-102)$ & $(82.5-107.5)$ & $(88-140)$ \\
\hline \multirow[t]{2}{*}{ EP } & $117.18 \pm 20.88$ & $165 \pm 7.4$ & $149.76 \pm 8.33$ & $131.25 \pm 8.34$ & 203 \\
\hline & $(83.52-173.32)$ & $(152.5-175)$ & $(122-162)$ & $(117.5-150)$ & $(105-240)$ \\
\hline \multirow[t]{2}{*}{ ES } & $123.13 \pm 10.04$ & $137.25 \pm 6.48$ & $133.63 \pm 6.77$ & $135.83 \pm 5.62$ & 180 \\
\hline & $(104.4-141.52)$ & $(125-148)$ & $(108-145)$ & $(125-150)$ & $(162-200)$ \\
\hline \multirow[t]{2}{*}{$\mathrm{TL}$} & $41.58 \pm 0.39$ & $71.5 \pm 4.32$ & $54.46 \pm 4.83$ & $67.41 \pm 4.61$ & 93 \\
\hline & $(20.88-53.36)$ & $(62.5-80.0)$ & $(40-65)$ & $(60-77.5)$ & $(75-108)$ \\
\hline \multirow[t]{2}{*}{$\mathrm{ABW}$} & $48.36 \pm 12.30$ & NA & $27.7 \pm 3.79$ & $26.25 \pm 2.6$ & 45 \\
\hline & $(27.84-69.6)$ & & $(23-40)$ & $(22.5-32.5)$ & $(33-55)$ \\
\hline \multirow[t]{2}{*}{$\mathrm{V}$} & $45.61 \pm 2.69$ & $49.88 \pm 5.2$ & $46.73 \pm 2.37$ & $46.51 \pm 1.52$ & 45 \\
\hline & $(39.2-49.68)$ & $(40.7-69.7)$ & $(41-50)$ & $(42.7-48.9)$ & $(42-48)$ \\
\hline
\end{tabular}

a gamma distribution ( shape parameter $=2.25$ ). These evolutionary analyses were carried out by the MEGA5 software (Tamura et al., 2011).

\section{Results}

\subsection{PCA analysis}

Morphometric variation was greatest between $H$. argentinensis and all other $H$. bacteriophora isolates. Heterorhabditis argentinensis was separated from the rest of $H$. bacteriophora populations for juveniles, males, amphimictic and hermaphroditic females (see Figure 1 A-D).

An accumulated variability of $91 \%$ was reached in hermaphroditic females by the PC1 (76\%) and PC2 (15\%). Except for NR and $\mathrm{V}$, all variables showed positive correlation between them and were responsible of the great variability of the PC1. Heterorhabditis argentinensis hermaphroditic females differed from the other H. bacteriophora populations due to larger dimensions. Heterorhabditis bacteriophora OLI and RIV strains were more similar than the other $H$. bacteriophora strains. The variable $\mathrm{V}$ was responsible to the major variability of the PC2 (see Figure 1A).

As well as hermaphrodites, all morphometric characters for amphimictic females, except $\mathrm{V}$ and $\mathrm{NR}$, explained the PC1 variability ( $72.8 \%$ of the total) and had a positive and high correlation. The variable V was correlated with PC2 and separated one of isolates of $H$. bacteriophora (OLI). $\mathrm{RN}$ and RIV strains of $H$. bacteriophora were most similar. Heterorhabditis argentinensis was separated from the rest of populations (see Figure 1B).
Males showed the greatest morphometric differences, being the five strains individually separated by PCA analysis. Results of the first two principal components for males explained $68.9 \%$. The $\mathrm{PC} 1$ separated $H$. argentinensis from the other $H$. bacteriophora populations by MBW, TL, L and EP variables. L, MBW, EP, ES, TL and GuL were responsible of the major variability in the PC1, while TRL and SpL defined PC2. Heterorhabditis bacteriophora VELI strain was separated from the others by a high value of TRL (see Figure 1C).

The infective juvenile was the stage with lower variability between strains and the best to discriminate Argentinian populations. The principal components 1 and 2 accounted for $48 \%$ (PC1) and $28 \%$ (PC2) respectively of the total variation of juveniles $(76.3 \%)$. Three groups were evident, one formed by $H$. bacteriophora OLI, RIV and RN strains, one for $H$. bacteriophora VELI strain, and one for $H$. argentinensis (see Figure 1D). The variable L and MBW were highly related to $H$. argentinensis, while ES and TL separated H. bacteriophora (OLI, RIV, RN strains) and EP H. bacteriophora VELI strain.

\subsection{Phylogenetic analysis}

In our phylogenetic tree, Heterorhabditis spp. formed three separate clades. The bioinformatic study placed $H$. argentinensis as a member of the clade B (100\% support of the most ancestral node), related to six populations of $H$. bacteriophora (among them the argentine VELI strain), five populations of $H$. georgiana, one isolate of H. zealandica, and two isolates of Heterorhabditis sp. 
Table 4. Morphometrics (mean and range) of males of Heterorhabditis isolates provided by the bibliography. All measurements are in $\mu \mathrm{m}$ (H. b: H. bacteriophora; NA: not available).

\begin{tabular}{|c|c|c|c|c|c|}
\hline \multirow{2}{*}{ Characters } & \multicolumn{5}{|c|}{ Males } \\
\hline & H.b. VELI & H.b. OLI & H.b. RIV & H.b. RN & H. argentinensis \\
\hline \multirow[t]{2}{*}{$\mathrm{L}$} & $822.46 \pm 83.16$ & $910 \pm 60$ & $845 \pm 57$ & $938 \pm 44$ & 1,500 \\
\hline & $(711-972)$ & $(800-1005)$ & $(700-940)$ & $(850-1,003)$ & $(1,000-2,000)$ \\
\hline \multirow[t]{2}{*}{ MBW } & $46.89 \pm 6.61$ & $48.05 \pm 3.86$ & $44.5 \pm 2.7$ & $43.56 \pm 1.63$ & 56 \\
\hline & $(42.3-62.6)$ & $(40-57)$ & $(37-47)$ & $(40-47)$ & $(42-70)$ \\
\hline \multirow[t]{2}{*}{ STL } & $5.22 \pm 1.71$ & $7.15 \pm 0.93$ & $6 \pm 0.6$ & NA & 5 \\
\hline & $(2.35-4.28)$ & $(6-9)$ & $(5-7)$ & & $(3.5-6.0)$ \\
\hline \multirow[t]{2}{*}{ STW } & $4.264 \pm 1.15$ & $5.25 \pm 0.55$ & $5.05 \pm 0.51$ & NA & 4 \\
\hline & $(2.35-6.9)$ & $(4-6)$ & $(4-6)$ & & $(2.5-5.0)$ \\
\hline \multirow[t]{2}{*}{ NR } & $66.39 \pm 10.21$ & $51.9 \pm 4.45$ & $77.25 \pm 3.43$ & $77.46 \pm 3.78$ & 72 \\
\hline & $(39.9-81.2)$ & $(45-62)$ & $(70-85)$ & $(70-85)$ & $(64-82)$ \\
\hline \multirow[t]{2}{*}{ EP } & $110.17 \pm 22.31$ & $125.9 \pm 7.6$ & $129.15 \pm 4.57$ & $88.36 \pm 4.52$ & 157 \\
\hline & $(95.12-134.5)$ & $(113-140)$ & $(120-137)$ & $(78-98)$ & $(145-170)$ \\
\hline \multirow{2}{*}{ ES } & $116.07 \pm 12.40$ & $101.4 \pm 4.69$ & $102.3 \pm 3.34$ & $101.9 \pm 3.06$ & 113 \\
\hline & $(104.4-141.52)$ & $(92.5-107.5)$ & $(95-110)$ & $(94-107)$ & $103-120$ \\
\hline \multirow{2}{*}{ TRL } & $200.78 \pm 77.98$ & 96 & $88.7 \pm 11.5$ & 97.23 & 133 \\
\hline & (103.4-229.68) & $(54-210)$ & $(75-115)$ & $(80-114)$ & $(100-194)$ \\
\hline \multirow[t]{2}{*}{ TL } & $27.95 \pm 8.47$ & $28.9 \pm 2.27$ & $24.35 \pm 1.56$ & $30.33 \pm 2.03$ & 37 \\
\hline & $(22.0-41.76)$ & $(24-33)$ & $(20-27)$ & $(26-35)$ & $(28-49)$ \\
\hline \multirow[t]{2}{*}{ ABW } & $36.91 \pm 10.97$ & NA & NA & $20.2 \pm 1.42$ & 24 \\
\hline & $(27-8-44.08)$ & & & $(18-25)$ & $(21-30)$ \\
\hline \multirow[t]{2}{*}{$\mathrm{SpL}$} & $45.00 \pm 4.76$ & $46.8 \pm 2.86$ & $43.2 \pm 1.96$ & $48.03 \pm 2.1$ & 46 \\
\hline & $(34.8-48.7)$ & $(40-51)$ & $(39-47)$ & $(45-53)$ & $(42-49)$ \\
\hline \multirow[t]{2}{*}{$\mathrm{SpW}$} & $4.64 \pm 0.66$ & NA & NA & NA & NA \\
\hline & $(3.48-5.8)$ & & & & \\
\hline \multirow[t]{2}{*}{ GuL } & $22.5 \pm 6.49$ & $22.9 \pm 2.22$ & $20.6 \pm 1.35$ & $19.2 \pm 2.32$ & 23 \\
\hline & $(18.5-21.1)$ & $(19-27)$ & $(18-24)$ & $(14-23)$ & $(20-26)$ \\
\hline \multirow[t]{2}{*}{ GuW } & $5.21 \pm 1.37$ & NA & NA & NA & NA \\
\hline & (3.94-6.96) & & & & \\
\hline GS & $0.53 \pm 0.13$ & NA & NA & NA & NA \\
\hline (GuL/SpL) & $(0.48-0.55)$ & & & & \\
\hline SW & $10.28 \pm 2.09$ & NA & NA & NA & NA \\
\hline (SpL/ABW) & $(7.29-14.0)$ & & & & \\
\hline $\mathrm{E}$ & $4.32 \pm 3.11$ & NA & NA & NA & NA \\
\hline$(\mathrm{EP} / \mathrm{TL})$ & $(2.96-5.65)$ & & & & \\
\hline $\mathrm{D}$ & $1.11 \pm 0.18$ & NA & NA & NA & NA \\
\hline (EP/ES) & $(0.89-1.17)$ & & & & \\
\hline $\mathrm{L} / \mathrm{TL}$ & $35.62 \pm 19.58$ & NA & NA & NA & NA \\
\hline & $(21.36-44.18)$ & & & & \\
\hline L/MBW & $19.31 \pm 3.64$ & NA & NA & NA & NA \\
\hline & $(13.5-22.97)$ & & & & \\
\hline MBW/TL & $1.57 \pm 1.09$ & NA & NA & NA & NA \\
\hline & $(1.1-2.7)$ & & & & \\
\hline
\end{tabular}

(see Figure 2; Table 6). Within the above set of sequences, the genetic similarities between $H$. argentinensis and the other members of the clade B varied between 98.3 and $100 \%$; and this isolate proved to be included in a subgroup together with five isolates of $H$. bacteriophora, where the similarities were between $99.4 \%$ and $99.7 \%$.
In clade B, H. bacteriophora HP88, N-KMD7, and 190-C strains had identical nucleotide sequences. Similarly, the strains of $H$. georgiana N-SPCM3, N-GPS29, N-KMD82 and $H$. zealandica NZH3 contained no differences (Table 6). However, the Argentinian H. bacteriophora VELI strain, differed from the above three $\mathrm{H}$. bacteriophora populations 
Table 5. Morphometrics (mean and range) of infective juveniles of Heterorhabditis isolates provided by the bibliography. All measurements are in $\mu \mathrm{m}$ (H. b: H. bacteriophora; NA: not available).

\begin{tabular}{|c|c|c|c|c|c|}
\hline \multirow{2}{*}{ Characters } & \multicolumn{5}{|c|}{ Infective juveniles } \\
\hline & H.b. VELI & H.b. OLI & H.b. RIV & H.b. RN & H. argentinensis \\
\hline \multirow[t]{2}{*}{$\mathrm{L}$} & $616.75 \pm 60.95$ & $540 \pm 0.03$ & $590 \pm 29.57$ & $603 \pm 19.67$ & 657 \\
\hline & $(505.04-675.12)$ & $(490-610)$ & $(540-640)$ & $(560-640)$ & $(610-710)$ \\
\hline \multirow[t]{2}{*}{ MBW } & $25.04 \pm 1.6$ & $23 \pm 1.03$ & $25.45 \pm 2.35$ & $23 \pm 0.78$ & 31 \\
\hline & $(23.2-27.84)$ & $(22-45)$ & $(22-29)$ & $(22-25)$ & $(24-38)$ \\
\hline \multirow[t]{2}{*}{$\mathrm{EP}$} & $100.11 \pm 12.34$ & $93.95 \pm 2.96$ & $100.4 \pm 3.74$ & $96.76 \pm 4.93$ & 95 \\
\hline & $(78.8-109.04)$ & $(87-101)$ & $(96-110)$ & $(90-112)$ & $(82-116)$ \\
\hline \multirow[t]{2}{*}{ ES } & $101.93 \pm 14.46$ & $112 \pm 4.68$ & $121.4 \pm 4.92$ & $116.3 \pm 4.16$ & 107 \\
\hline & $(74.24-113.68)$ & $(103-119)$ & $(110-130)$ & $(108-122)$ & $(68-122)$ \\
\hline \multirow[t]{2}{*}{$\mathrm{TL}$} & $38.54 \pm 14.3$ & $89.6 \pm 10.22$ & $93.4 \pm 4$ & $101.5 \pm 6.72$ & 84 \\
\hline & $(32.16-51.4)$ & $(72-105)$ & $(85-100)$ & $(88-113)$ & $(70-105)$ \\
\hline \multirow[t]{2}{*}{$\mathrm{ABW}$} & $18.63 \pm 3.25$ & NA & $15.9 \pm 0.75$ & $15.25 \pm 1.2$ & NA \\
\hline & $(15.08-27.84)$ & & $(14-17)$ & $(13-17)$ & \\
\hline \multirow[t]{2}{*}{ Ratio a (L/MBW) } & $23.76 \pm 3.03$ & $23.44 \pm 1.01$ & $23.6 \pm 1.5$ & $26.24 \pm 1.16$ & NA \\
\hline & $(22.2-26.2)$ & $(20.4-25)$ & $(20-26)$ & $(23.75-28.63)$ & \\
\hline \multirow[t]{2}{*}{ Ratio b (L/ES) } & $6.19 \pm 1.2$ & $4.77 \pm 0.24$ & $4.92 \pm 0.3$ & $5.18 \pm 0.17$ & NA \\
\hline & $(5.3-8.8)$ & $(4.3-5.2)$ & $(4.5-5.8)$ & $(4.9-5.6)$ & \\
\hline \multirow[t]{2}{*}{ Ratio c (L/TL) } & $9.87 \pm 3.63$ & $6.07 \pm 0.79$ & $6.39 \pm 0.19$ & $5.95 \pm 0.37$ & NA \\
\hline & $(6.2-14.4)$ & $(4.9-7.6)$ & $(6.1-6.8)$ & $(5.22-6.66)$ & \\
\hline \multirow[t]{2}{*}{ Ratio d (EP/ES) } & $0.99 \pm 0.14$ & $0.84 \pm 0.02$ & $0.82 \pm 0.05$ & $0.83 \pm 0.03$ & NA \\
\hline & $(0.62-1.07)$ & $(0.8-0.88)$ & $(0.75-0.9)$ & $(0.77-0.94)$ & \\
\hline \multirow[t]{2}{*}{ Ratio e (EP/TL) } & $1.54 \pm 0.39$ & $1.0 \pm 0.14$ & $1.07 \pm 0.06$ & $0.95 \pm 0.07$ & NA \\
\hline & $(1.9-2.1)$ & $(0.8-1.3)$ & $(0.98-1.2)$ & $(0.82-1.1)$ & \\
\hline
\end{tabular}

in one nucleotide at position 176 (a T vs. C transition), whereas $H$. argentinensis did so with respect to an insertion of a $\mathrm{C}$ at position 348. The latter species also exhibited variation at three positions with respect to $H$. bacteriophora N-KMD6 (at nucleotides 97, 176, and 231) and to H. bacteriophora 51-C (at nucleotides 176, 295, and 310). Greater differences were observed between VELI strain and $H$. georgiana populations (between 4 and 5 different nucleotides; Table 6).

The clade A (100\% support of the most ancestral node) comprised all species isolated from the Southern Asia and Indian-Ocean region: five isolates of $H$. indica, one isolate of $H$. gerrardi, and two Heterorhabditis $s p$.

The remaining group, clade $\mathrm{C}$ (100\% support of the most ancestral node), comprised five species: $H$. marelatus, $H$. safricana, $H$. atacamensis, $H$. downesi, and $H$. megidis. Also, this clade was composed of five subgroups (51-100\% support; see Figure 2). Length of expected amplicon for the species analyzed in this phylogenetic study (without considering primers used for each case) varied between 829 and 830 bp in clade A, 861-862 bp in clade B, and $836-851$ bp in clade $\mathrm{C}$. These results are in accordance with the similarity levels data obtained within clades by phylogenetic inference, indicating a major homogeneity between $H$. bacteriophora populations.

\section{Discussion}

Two species of heterorhabditid nematodes were reported for Argentina: six isolates of $H$. argentinensis in Santa Fe and La Pampa provinces (Stock, 1993, 1995), and more than 20 populations of Heterorhabditis bacteriophora reported in the central-pampean region, Cuyo and Patagonia (Doucet and Bertolotti, 1996; Giayetto and Cichón, 2006; Del Valle et al., 2013).

Studies on the morphometric variability are useful to provide valuable information about geographical and ecological requirements for EPN. Morphometric differences can be observed in nematode strains isolated from different sites and hosts (Campos Herrera et al., 2006).

In our study, morphometric variations were observed according to Nguyen (2016) which considered some morphological features as highly variables for Argentinian strains. The greatest differences were registered between $H$. argentinensis and all other $H$. bacteriophora populations, unlike between $H$. bacteriophora strains from different regions.

Results of PCA analysis for morphometric characters separated $H$. argentinensis from the rest of $H$. bacteriophora strains from Argentina, considering the four nematode stages. The infective juvenile was a stage with high weight in the separation between Heterorhabditis populations. Three groups were separated considering PC1 and PC2 

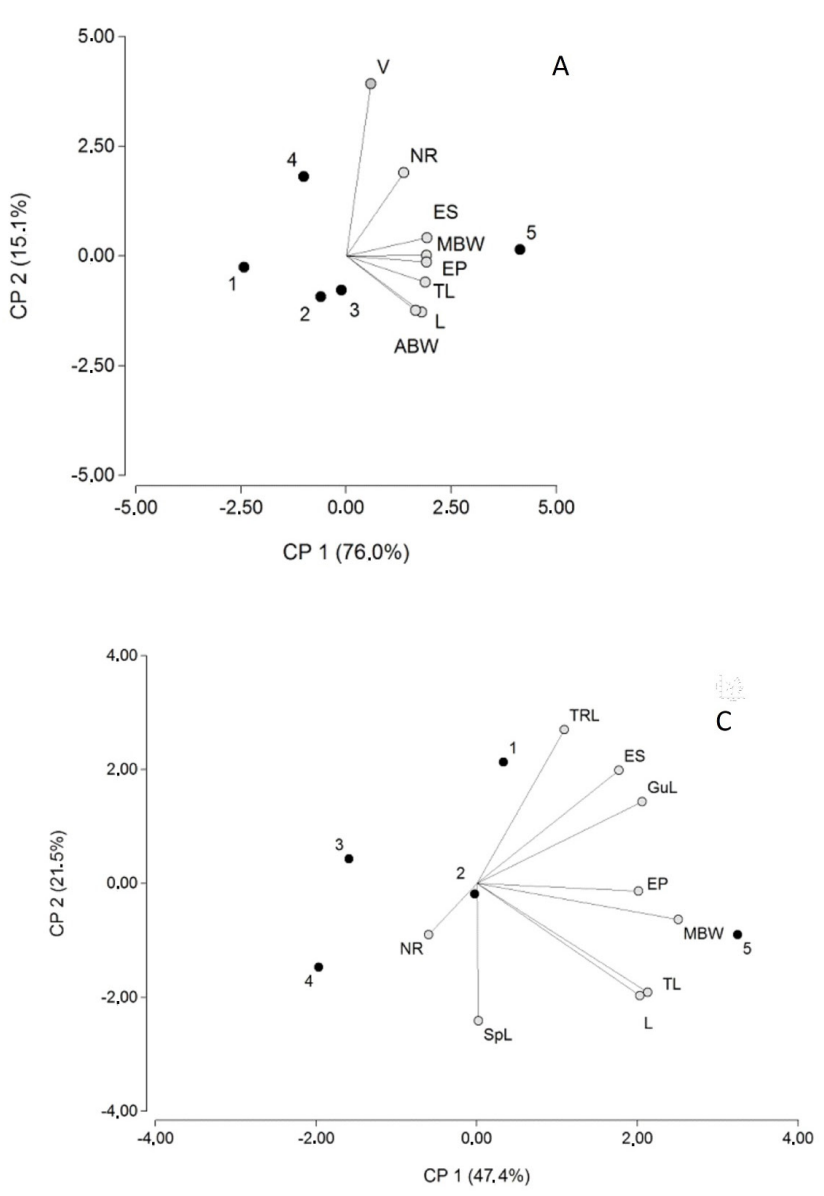
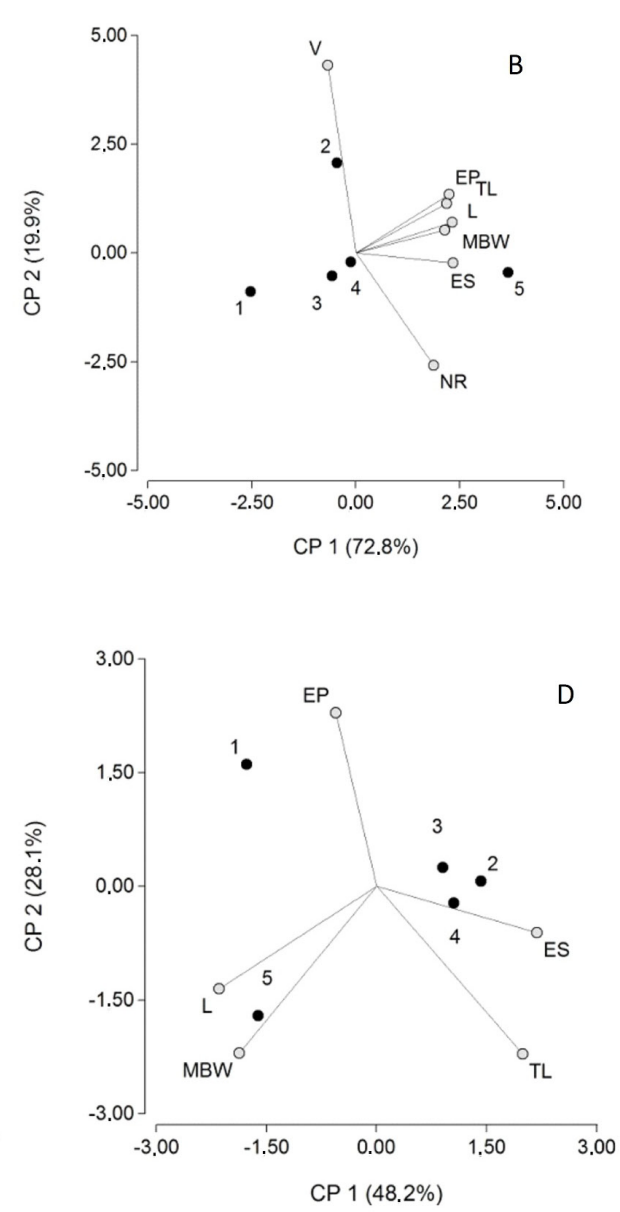

Figure 1. Principal component analysis of Heterorhabditis spp., based on mean values of morphometric characters for all nematode stages. (A) =Hermaphroditic females, (B) =Amphimictic females, (C) =Males, (D) =Infective juveniles. (H. bacteriophora strains: 1. VELI, 2. OLI, 3. RIV, 4. RN; 5: H. argentinensis).

for this stage; one formed by $H$. bacteriophora OLI, RIV and RN strains, one for H. bacteriophora VELI strain and one for $H$. argentinensis. The variable $\mathrm{L}$ was negatively correlated with TL for juveniles, showing that longer specimens had shorter tails. Measurements of males and infective juveniles were suggested for several authors as the most suitable for the distinction among heterorhabditid populations (Adams et al., 1998; Dolinski et al., 2008) although in our study males were not as good as juveniles.

Morphometric characteristics of $H$. bacteriophora strain VELI, were slightly larger respect to other Argentinian isolates of the same species, which was observed always separated from the rest of populations by PCA analysis. However, these variations were not as considerable as in H. argentinensis.

Even though morphometric study separated $H$. argentinensis from the rest of $H$. bacteriophora isolates, the phylogenetic analysis placed in the same clade $H$. argentinensis and six populations of $H$. bacteriophora. The genetic similarity between $H$. bacteriophora populations and H. argentinensis was over $99 \%$. Heterorhabditis bacteriophora VELI strain and $H$. argentinensis had the same number of nucleotide-sequence variations with respect to the rest of the $H$. bacteriophora isolates analyzed in our study. The Argentinian isolations exhibited two differences in nucleotide sequence: a $\mathrm{T} v$ s. C at position 176 of ITS1-rDNA (constituting a new variation in coding sequence) in H. bacteriophora (VELI strain) and a $\mathrm{C}$ inserted at position 348 in Heterorhabditis argentinensis. These nucleotide variations were not present in the rest of H. bacteriophora member of the clade B. Results obtained in our study are according to Adams et al. (1998) and Phan et al. (2003) who analyzing DNA sequences of the ITS1 of the Heterorhabditis genus, showed the type strain $H$. bacteriophora (HB1) differing from $H$. argentinensis in a single transversion (G vs. C) at position 620 (Adams et al., 1998; Phan et al., 2003) and in a single insertion of a $\mathrm{C}$ at position 348 as we mentioned (Phan et al., 2003). Therefore, by the results obtained in our study, $H$. argentinensis would be a sister taxa of $H$. bacteriophora, as was considered by Adams et al. (1998). 


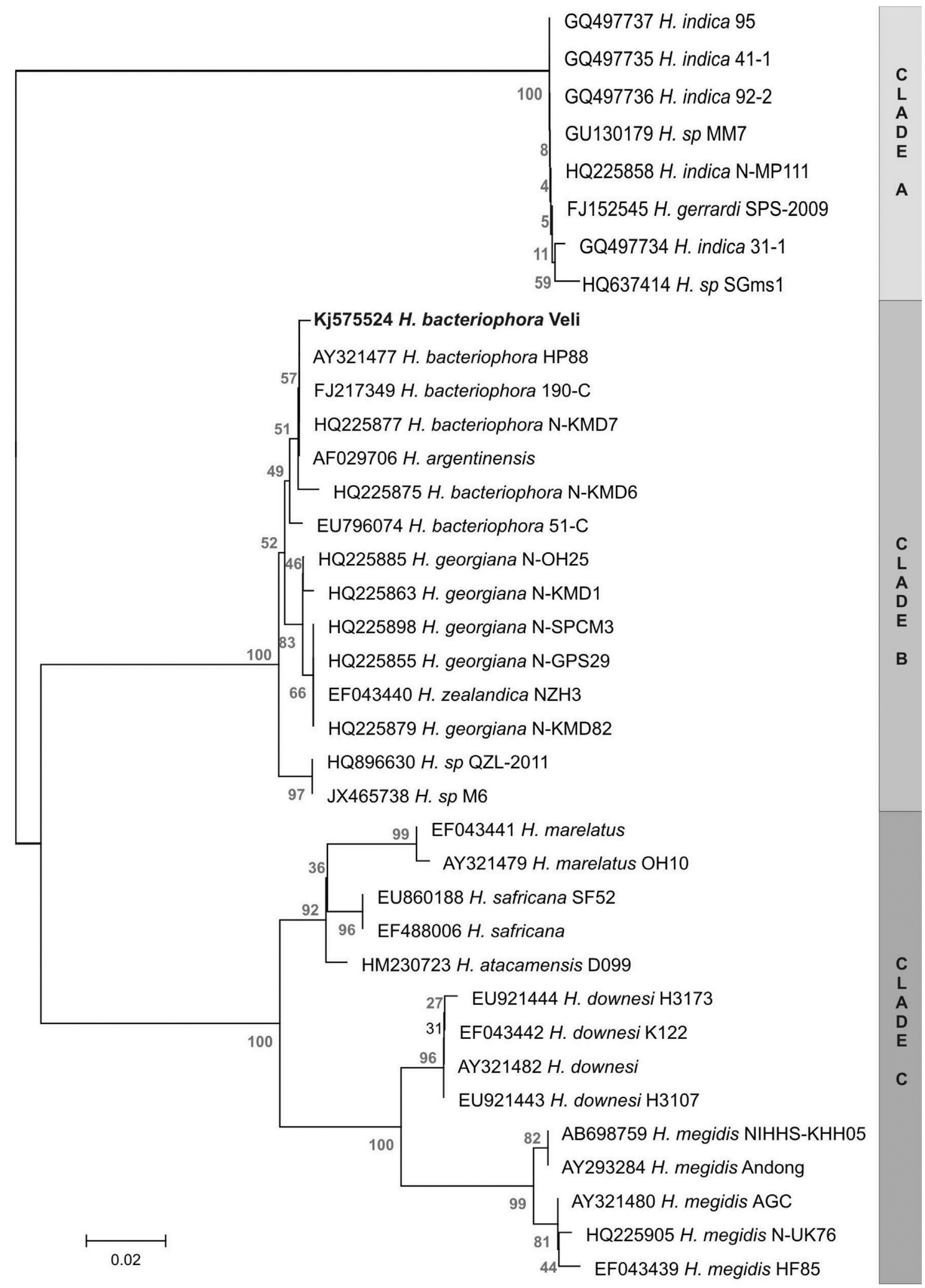

Figure 2. Evolutionary relationships among Heterorhabditis taxa. The percentage of replicate trees in which the associated taxa clustered together in the bootstrap test (1,000 replicates) is shown next to the branches, Felsenstein (1985). Only node consistencies above $40 \%$ are shown. The tree is drawn to scale, with branch lengths in the same proportions as the evolutionary distances used to infer the phylogenetic tree. 
Table 6. Nucleotide differences between populations of Heterorhabditis spp. within the Clade B.

\begin{tabular}{|c|c|c|c|c|c|c|c|c|c|c|c|c|c|c|c|}
\hline $\begin{array}{c}\text { Alignment } \\
\text { relative } \\
\text { position }\end{array}$ & 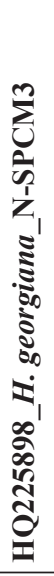 & 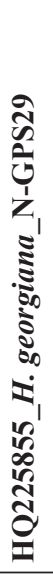 & 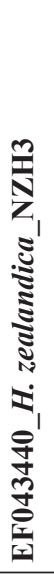 & 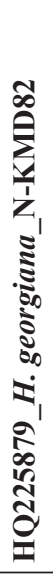 & 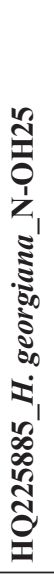 & 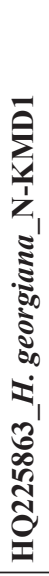 & 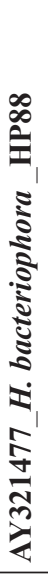 & 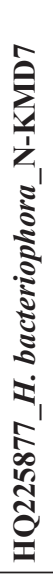 & 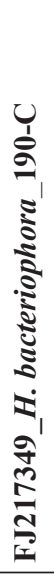 & 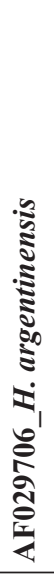 & 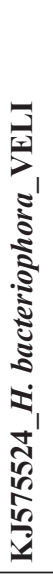 & 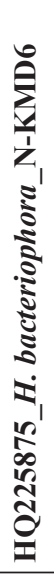 & 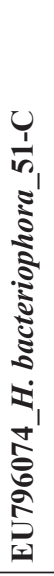 & 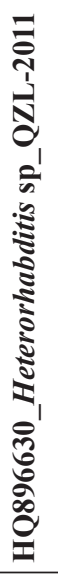 & 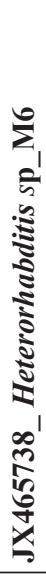 \\
\hline 5 & $\mathrm{~T}$ & $\mathrm{~T}$ & $\mathrm{~T}$ & $\mathrm{~T}$ & $\mathrm{G}$ & $\mathrm{G}$ & G & $\mathrm{G}$ & $\mathrm{G}$ & $\mathrm{G}$ & $\mathrm{G}$ & $\mathrm{G}$ & $\mathrm{G}$ & $\mathrm{G}$ & $\mathrm{G}$ \\
\hline 97 & $\mathrm{~T}$ & $\mathrm{~T}$ & $\mathrm{~T}$ & $\mathrm{~T}$ & $\mathrm{~T}$ & $\mathrm{~T}$ & $\mathrm{~T}$ & $\mathrm{~T}$ & $\mathrm{~T}$ & $\mathrm{~T}$ & $\mathrm{~T}$ & $\mathrm{C}$ & $\mathrm{T}$ & $\mathrm{T}$ & $\mathrm{T}$ \\
\hline 176 & $\mathrm{~T}$ & $\mathrm{~T}$ & $\mathrm{~T}$ & $\mathrm{~T}$ & $\mathrm{~T}$ & $\mathrm{~T}$ & $\mathrm{~T}$ & $\mathrm{~T}$ & $\mathrm{~T}$ & $\mathrm{~T}$ & $\mathrm{C}$ & $\mathrm{T}$ & $\mathrm{T}$ & $\mathrm{T}$ & $\mathrm{T}$ \\
\hline 204 & $\mathrm{G}$ & $\mathrm{G}$ & $\mathrm{G}$ & $\mathrm{G}$ & $\mathrm{G}$ & G & $\mathrm{C}$ & $\mathrm{C}$ & $\mathrm{C}$ & $\mathrm{C}$ & $\mathrm{C}$ & $\mathrm{C}$ & $\mathrm{C}$ & $\mathrm{C}$ & $\mathrm{C}$ \\
\hline 214 & $\mathrm{~T}$ & $\mathrm{~T}$ & $\mathrm{~T}$ & $\mathrm{~T}$ & $\mathrm{~T}$ & $\mathrm{~T}$ & $\mathrm{~T}$ & $\mathrm{~T}$ & $\mathrm{~T}$ & $\mathrm{~T}$ & $\mathrm{~T}$ & $\mathrm{~T}$ & $\mathrm{~T}$ & $\mathrm{C}$ & $\mathrm{C}$ \\
\hline 225 & $\mathrm{~A}$ & A & A & $\mathrm{A}$ & $\mathrm{A}$ & G & A & A & $\mathrm{A}$ & $\mathrm{A}$ & A & $\mathrm{A}$ & A & A & A \\
\hline 229 & $\mathrm{~A}$ & A & A & A & $\mathrm{A}$ & A & A & A & $\mathrm{A}$ & $\mathrm{A}$ & A & $\mathrm{A}$ & $\mathrm{A}$ & $\mathrm{T}$ & $\mathrm{T}$ \\
\hline 230 & $\mathrm{C}$ & $\mathrm{C}$ & $\mathrm{C}$ & $\mathrm{C}$ & $\mathrm{C}$ & $\mathrm{C}$ & $\mathrm{C}$ & $\mathrm{C}$ & $\mathrm{C}$ & $\mathrm{C}$ & $\mathrm{C}$ & $\mathrm{C}$ & $\mathrm{C}$ & A & A \\
\hline 231 & $\mathrm{~A}$ & A & A & $\mathrm{A}$ & A & A & A & A & $\mathrm{A}$ & $\mathrm{A}$ & A & $\mathrm{G}$ & A & A & A \\
\hline 233 & $\mathrm{~T}$ & $\mathrm{~T}$ & $\mathrm{~T}$ & $\mathrm{~T}$ & $\mathrm{~T}$ & $\mathrm{~T}$ & A & A & A & A & A & A & A & $\mathrm{C}$ & $\mathrm{C}$ \\
\hline 295 & $\mathrm{C}$ & $\mathrm{C}$ & $\mathrm{C}$ & $\mathrm{C}$ & $\mathrm{C}$ & $\mathrm{C}$ & $\mathrm{G}$ & $\mathrm{G}$ & $\mathrm{G}$ & $\mathrm{G}$ & $\mathrm{G}$ & $\mathrm{G}$ & $\mathrm{C}$ & $\mathrm{C}$ & $\mathrm{C}$ \\
\hline 310 & $\mathrm{C}$ & $\mathrm{C}$ & $\mathrm{C}$ & $\mathrm{C}$ & $\mathrm{C}$ & $\mathrm{C}$ & $\mathrm{C}$ & $\mathrm{C}$ & $\mathrm{C}$ & $\mathrm{C}$ & $\mathrm{C}$ & $\mathrm{C}$ & A & $\mathrm{C}$ & $\mathrm{C}$ \\
\hline 348 & -- & -- & -- & -- & -- & -- & -- & -- & -- & $\mathrm{C}$ & -- & -- & -- & -- & -- \\
\hline
\end{tabular}

Morphometry of the parasites can be influenced by nutritional conditions inside the host, and environmental factors (Phan et al., 2003; Canto-Silva, et al., 2005). Stock and Mrácek (2000), mentioned that the geographical origin and habitat can influence on morphometric data, so even values obtained from a same host can change based on abiotic factors and rearing conditions. Boff et al. (2000) observed that a larger body size of the host and a lower dose of infection increased the size of IJs of Heterorhabditis megidis. These variations could be produced because measurements often are taken from the progeny of a few soil-baited insect hosts, so is unlikely that they represent the range of variation present in the population (Adams et al., 1998).

In Argentina, Heterorhabditis spp. populations were isolated from different locations and hosts. Heterorhabditis argentinensis was found parasitizing the alfalfa weevil Graphognathus sp. (Coleoptera: Curculionidae) (Stock, 1993), from Santa Fe province, H. bacteriophora RIV strain from Heliothis sp. (Lepidoptera: Noctuidae) from Cordoba province, and both were later maintained in the laboratory in Galleria mellonella larvae (Lepidoptera) for the identification; meanwhile Heterorhabditis bacteriophora OLI strain, from Córdoba province, RN strain from Río Negro province and VELI strain from Buenos Aires province were isolated directly from field, in Galleria mellonella baits, leaving the natural hosts unknown (Aguera de Doucet and Doucet, 1986; Stock, 1995; Doucet and Bertolotti, 1996; Giayetto and Cichon, 2006). Geographically, Argentina is divided in different regions determined by a homogeneous relief and climate. Rainfalls decrease from east to west, from Mesopotamia to the mountains by the rainfall regime of the Atlantic. From there we can find humid climates, with over $800 \mathrm{~mm}$ per year, less than $400 \mathrm{~mm}$ dry climates and arid and semiarid in the transition zone between both (Bianchi and Cravero, 2010). Buenos Aires and Santa Fe provinces, where H. bacteriophora VELI and $H$. argentinensis strains were isolated, present more rainfalls and humidity conditions, respect the other sites. These requirements could have influenced on the larger dimensions observed in H. bacteriophora VELI and $H$. argentinensis populations, as the conditions of the host at the time to be isolated from the field.

In the same way, the average annual temperature declines in the plains of central and northeastern of Argentina with increasing latitude. The "Río Negro"river where the upper Valley of Río Negro province is located, and where $H$. bacteriophora RN strain was isolated, born at the eastern end of the province of Neuquen, and flows to the Río Negro territory in southeast direction to reach the Atlantic Ocean, being in its last leg the natural boundary between the provinces of Rio Negro and 
Buenos Aires. The presence of mountains and plateaus in the west and south of the 'Río Negro" river, deflects the isotherms, which take a parallel course to the mountain, producing a decreasing of the temperatures to the south of the country. According to this parameter, in Argentina can be distinguished subtropical climates, with annual average temperatures above $18{ }^{\circ} \mathrm{C}$, temperate, ranging between $18{ }^{\circ} \mathrm{C}$ and $12{ }^{\circ} \mathrm{C}$, and cold climates, less than $12{ }^{\circ} \mathrm{C}$ (Bianchi and Cravero, 2010). While all Argentinian strains were isolated from temperate climates, the average annual temperature for Santa Fe province $\left(18^{\circ} \mathrm{C}\right)$ is at the limit between a mild and subtropical climate, which also could have influenced the largest morphometry reached by $H$. argentinensis.

Considering the results of this study, morphometric variations are present between Argentinian populations of Heterorhabditis spp. isolated from different regions. In this way, Heterorhabditis argentinensis would be conspecific to $H$. bacteriophora, constituting a strain with a great morphometric variation where the host and climatic conditions could have influenced on the measurements.

This work constituted the first comparative and phylogenetic study of heterorhabditid populations from Argentina.

\section{Acknowledgements}

This study was partially supported by Consejo Nacional de Investigaciones Científicas y Técnicas (CONICET), PIP 2010/0170, Universidad Nacional de La Plata, (UNLP), and Agencia Nacional de Promoción Científica y Tecnológica, Argentina, PICT 2011/1439. We thank to Dra. Graciela Minardi, and Carlos A. Galliari (CEPAVE), for statistical assistance and Dr. Larry Duncan (UF/IFAS) a native English speaker, and referent in entomopathogenic nematodes for his suggestions and editing of the final version of the manuscript.

\section{References}

ADAMS, B.J., BURNELL, A.M. and POWERS, T.O., 1998. A phylogenetic analysis of Heterorhabditis (Nemata: Rhabditidae) based on internal transcribed spacer 1 DNA sequence data. Journal of Nematology, vol. 30, no. 1, pp. 22-39. PMid:19274196.

AGÜERA DE DOUCET, M.M. and DOUCET, M.E., 1986. Nuevos datos para el conocimiento de Heterorhabditis bacteriophora Poinar, 1975. Revista de Investigaciones Agropecuarias INTA, vol. XXI, pp. 1-10.

BIANCHI, A. and CRAVERO, S., 2010. Atlas climático digital de la República Argentina. Buenos Aires: Editorial INTA, Instituto Nacional de Tecnología Agropecuaria. 55 p.

BOFF, M.I.C., WIEGERS, G.L. and SMITS, P.H., 2000. Influences of host size and host species on the infectivity and development of Heterorhabditis megidis (strain NLH E87.3). BioControl, vol. 45, no. 4, pp. 469-482. http://dx.doi.org/10.1023/A:1026560208285.

CAMPOS-HERRERA, R., ESCUER, M., ROBERTSON, L. and GUTIÉRREZ, C., 2006. Morphological and Ecological Characterization of Steinernema feltiae (Rhabditida: Steinernematidae) Rioja Strain
Isolated from Bibio hortulanus (Diptera: Bibionidae) in Spain. Journal of Nematology, vol. 38, no. 1, pp. 68-75. PMid:19259432.

CANTO-SILVA, C.R., ROMANOWSKI, H.P. and REDAELLI, L.R., 2005. Effect of temperature on the development and viability of Gryon gallardoi (Brethes) (Hymenoptera: Scelionidae) parasitizing Spartocera dentiventris (Berg) (Hemiptera: Coreidae) eggs. Brazilian Journal of Biology $=$ Revista Brasileira de Biologia, vol. 65, no. 3, pp. 415-421. http://dx.doi.org/10.1590/ S1519-69842005000300006. PMid:16341419.

DEL VALLE, E., LAX, P., RONDÁN DUEÑAS, J. and DOUCET, M., 2013. Effects of insect cadavers infected by Heterorhabditis bacteriophora and Steinernema diaprepesi on Meloidogyne incognita parasitism in pepper and summer squash plants. Ciencia e Investigación Agraria, vol. 40, no. 1, pp. 109-118. http://dx.doi. org/10.4067/S0718-16202013000100009.

DOLINSKI, C., KAMITANI, F., MACHADO, I. and WINTER, C., 2008. Molecular and morphological characterization of heterorhabditid entomopathogenic nematodes from the tropical rainforest in Brazil. Memorias do Instituto Oswaldo Cruz, vol. 103 , no. 2 , pp. 150-159. http://dx.doi.org/10.1590/S007402762008000200005 . PMid:18425267.

DOUCET, M.M.A. and BERTOLOTTI, M.A., 1996. Una nueva población de Heterorhabditis bacteriophora Poinar, 1975 para Argentina. Caracterización y acción sobre el huésped. Nematologia Mediterranea, vol. 24, pp. 169-174.

DOUCET, M.M.A., BERTOLOTTI, M.A., and CAGNOLO, S.R., 1996. On a new isolate of Heterorhabditis bacteriophora Poinar, 1975 (Nematoda: Heterorhabditidae) from Argentina: life cycle and description of infective juveniles, female, males and hermaphrodites of 2 nd and 3 rd generations. Fundamental and Applied Nematology, vol. 19, pp. 415-420.

FELSENSTEIN, J., 1985. Confidence limits on phylogenies: an approach using the bootstrap. Evolution, International Journal of Organic Evolution, vol. 39, no. 4, pp. 783-791. http://dx.doi. org/10.2307/2408678

GIAYETTO, A.L. and CICHÓN, L.I., 2006. Distribución, gama de huéspedes y especificidad de cinco poblaciones de Heterorhabditis bacteriophora (Nematoda: Heterorhabditidae) del Alto Valle de Río Negro y Neuquén, Argentina. RIA, vol. 35, no. 2, pp. 163-183.

HOMINICK, W.M., BRISCOE, B.R., DEL PINO, F.G, HENG, J., HUNT, D.J., KOZODOY, E., MRACEK, Z., NGUYEN, K.B., REID, A.P., SPIRIDONOV, S., STOCK, P., STURHAN, D., WATURU, C. and YOSHIDA, M., 1997. Biosystematics of entomopathogenic nematodes: current status, protocols and definitions. Journal of Helminthology, vol. 71, no. 4, pp. 271-298. http://dx.doi.org/10.1017/S0022149X00016096. PMid:9443947.

NGUYEN, K.B., 2016 [viewed 4 April, 2016]. Morphology of bursa of Heterorhabditis spp. [online]. Gainesville: Institute of Food and Agricultural Sciences, University of Florida. Available from: http://entnemdept.ufl.edu/nguyen/ morph/het-bursa.htm

PHAN, K.L., SUBBOTIN, S.A., NGUYEN, N.C. and MOENS, M., 2003. Heterorhabditis baujardi sp. n. (Rhabditida: Heterorhabditidae) from Vietnam and morphometric data for H. indica populations. Nematology, vol. 5, no. 3, pp. 367-382. http://dx.doi.org/10.1163/156854103769224368.

SAITOU, N. and NEI, M., 1987. The neighbor-joining method: a new method for reconstructing phylogenetic trees. Molecular Biology and Evolution, vol. 4, no. 4, pp. 406-425. PMid:3447015. 
SALAS, A., ELICECHE, D., BELAICH, M. and ACHINELLY, M., 2013. Biología, patogenicidad y multiplicación de un aislamiento nativo del nematodo entomopatógeno Heterorhabditis bacteriophora proveniente de huertas de cultivo orgánico en Argentina. Nematropica, vol. 43, pp. 323.

STOCK, S.P. and MRÁCEK, Z., 2000. Morphological variation between allopatric populations of Steinernema krausei (Steiner, 1923) (Rhabditida: Steinernematidae). Nematology, vol. 2, no. 2, pp. 143-152. http://dx.doi.org/10.1163/156854100509033.

STOCK, S.P., 1993. Anew species of the genus Heterorhabditis Poinar, 1976 (Nematoda: Heterorhabditidae) parasitizing Graphognathus sp. Larva (Coleoptera: Curculionidae) from Argentina. Research and Reviews in Parasitology, vol. 53, pp. 103-107.
STOCK, S.P., 1995. Natural populations of entomopathogenic nematodes in the Pampean region of Argentina. Nematropica, vol. 25, pp. 143-148.

TAMURA, K., NEI, M. and KUMAR, S., 2004. Prospects for inferring very large phylogenies by using the neighbor-joining method. Proceedings of the National Academy of Sciences of the United States of America, vol. 101, no. 30, pp. 11030-11035. http://dx.doi.org/10.1073/pnas.0404206101. PMid:15258291.

TAMURA, K., PETERSON, D., PETERSON, N., STECHER, G., NEI, M. and KUMAR, S., 2011. MEGA5: Molecular Evolutionary Genetics Analysis using maximum likelihood, evolutionary distance, and maximum parsimony methods. Molecular Biology and Evolution, vol. 28, no. 10, pp. 2731-2739. http://dx.doi. org/10.1093/molbev/msr121. PMid:21546353. 